Işıkoğlu Erdoğan, N., Canbeldek, M. (2017). Erken Çocukluk Eğitiminde Ölçme ve Değerlendirme. Abant İzzet Baysal Üniversitesi Eğitim Fakültesi Dergisi, 17 (3), 1306-1327.

Geliş Tarihi: 07/02/2017

Kabul Tarihi: 16/08/2017

\title{
ERKEN ÇOCUKLUK EĞITTIMINDE ÖLÇME VE DEĞERLENDİRME
}

\author{
Nesrin IŞIKOĞLU ERDOĞAN* \\ Merve CANBELDEK **
}

\begin{abstract}
ÖZET
Çocukların gelişimlerini takip etmek ve desteklemek için erken çocukluk döneminde ölçme ve değerlendirme önemli bir yer tutmaktadır. Gelişim özellikleri dikkate alındığında, bu dönem çocuklarının eğitiminde diğer eğitim kademelerinden farklı ölçme ve değerlendirme yaklaşımlarına rastlanmaktadır. Formal, informal, alternatif, performansa dayalı değerlendirme olarak Türkçeye kazandırılmış olan bu yaklaşımlar alanda yaygın olarak kullanılsa da bu kavramların yabancı alan yazından çeviri yoluyla alınması bunlarla ilgili kavram çelişkilerine yol açmaktadır. Bu nedenle bu çalışmanın amacı, erken çocukluk eğitiminde ölçme ve değerlendirmede kullanılan yaklaşımların ve kavramların örneklerle açıklanmasına ve ortak kavramsal alt yapının oluşmasına katk1 sağlamaktır. Erken çocukluk eğitiminde kullanılan formal, informal ve alternatif değerlendirme yaklaşımları çerçevesinde temel ölçme ve değerlendirme kavramları bu makalede tartışılmıştır. Bu doğrultuda, öğretmen ve uzmanların çocukların gelişimlerini değerlendirmede kullanabilecekleri araçlar ve yöntemler örneklerle sunulmuştur.
\end{abstract}

Anahtar Kelimeler: Erken çocukluk eğitimi, formal değerlendirme, informal değerlendirme, alternatif değerlendirme

\section{ASSESSMENT AND EVALUATION IN EARLY CHILDHOOD EDUCATION}

\begin{abstract}
To monitor children's progress and support their development, assessment and evaluation play an important role in early childhood education. Considering developmental changes in this period, in early childhood education uses various types of assessment and evaluation approaches which differ from the approaches other educational levels used for assessment. Formal, informal, alternative and performance based assessment are widely used approaches in the early childhood education. These approaches are often translated into Turkish from the global literature sometimes lead to concepts contradictions. For this reason, this review study aims to describe the common approaches and concepts related to early childhood assessment and evaluation. The widespread approaches and concepts including formal, informal and alternative evaluation were discussed. In this context, the methods and tools used to assess children's development were presented with examples of teachers and experts in the area.

Key Words: Early childhood education, formal assessment, informal assessment, alternative assessment
\end{abstract}

\footnotetext{
* Pamukkale Üniversitesi, Eğitim Fakültesi, Temel Eğitim Bölümü, Okul Öncesi Eğitimi, nisikoglu@pau.edu.tr

** Pamukkale Üniversitesi, Eğitim Fakültesi, Temel Eğitim Bölümü, Okul Öncesi Eğitimi, mcanbeldek@pau.edu.tr
} 


\section{GİRİs}

İnsanlar yaşamlarında, doğum öncesinden itibaren birçok kez ölçme ve değerlendirmeye tabi tutulmaktır. Bebek dünyaya gelmeden anne karnında gelişimi değerlendirilmekte, doğduğunda yaşamsal fonksiyonları Apgar ölçeği ile ölçülmektedir. Formal eğitimin başlangıcı olan erken çocukluk eğitiminde ise çocukların değerlendirilmesi gelişimlerinin desteklenmesi için oldukça önemlidir. Erken çocukluk döneminde ölçme ve değerlendirme, çocukların tüm gelişimleri hakkında bilgi sahibi olmak, çocuğun eğitim sürecinde gelişimini izlemek ve özel gereksinimli çocukları belirlemek amacıyla kullanılmaktadır. Çocukların gelişim özellikleri dikkate alındığında, erken çocukluk eğitiminde diğer eğitim kademelerinden farklı ölçme ve değerlendirme yaklaşımlarına rastlanılmaktadır. $\mathrm{Bu}$ dönemde ölçme değerlendirmede çoklu veri toplama yaklaşımlarının kullanılması gerçek bir değerlendirme için gereklidir (Saracho, 2015). Informal, formal, alternatif, performansa dayalı ölçme ve değerlendirme olarak Türkçeye kazandırılmış olan bu kavramlar alanda yaygın olarak kullanılmaktayken bu kavramların yabancı alan yazından çeviri yoluyla alınması da bunlarla ilgili kavram çelişkilerine yol açmaktadır. Örneğin, alan yazında alternatif değerlendirme başlığı altında standart testlerden bahseden yayınlar yer almaktadır. Bu nedenle, bu derleme araştırmada erken çocuk eğitiminde ölçme ve değerlendirme ile ilgili kavram ve yaklaşımların tanımlanması amaçlanmaktadır. Bu yolla alan yazında ortak kavramsal alt yapının oluşmasına katkı sağlamak hedeflenmektedir.

Erken çocukluk eğitiminde ölçme ve değerlendirme kavramları "gelişimsel değerlendirme" çerçevesinde ele alınmaktadır. Yaygın olarak kullanılan ölçme tanımları, örneğin "objelerin özelliklerini gözleyip gözlem sonuçlarını sayılarla ya da sembollerle ifade etme" (Turgut \& Baykul, 2010) gibi, erken çocukluk eğitiminde ölçme ve değerlendirmeyi tam olarak açıklamada yetersiz kalmaktadır. Gullo (2005) erken çocukluk eğitiminde ölçmeyi, "çocuğun bir niteliğe sahip olma derecesini belirlemek için kullanılan işlem" olarak tanımlarken, McAfee \& Leong (2012) ise "gelişim süreci hakkında bilgi toplama" olarak ifade etmiştir. Tanımlarda vurgulanan temel nokta ölçmenin çocuğun gelişimini tanımlamak için kullanılan bir kavram olmasıdır. Bu nedenle ölçme çocuğun gelişimine yönelik bir anlayış kazanmak için kullanılmaktadır.

Öte yandan, ölçmeden farklı olarak değerlendirme ise "çocukların gelişimlerine, öğrenmelerine, sınıf ortamına ve eğitsel etkinliklere ilişkin bilgilerin toplanması ve toplanan bilgiler aracılığıyla eğitime yönelik kararların verilebilmesi için bu bilgilerin düzenlenmesi ve yorumlanması süreci" olarak tanımlanmaktadır (McAfee, Leong \& Bodrova, 2004). Başka bir ifade ile değerlendirme, ölçmeden elde edilen sonuçlara göre karar vermeyi içermektedir. Yani, ölçme çocuğun gelişimini tanımlamak için veri toplama olarak tanımlanabilirken; değerlendirme bu verilerden çıkarımda ve yorumda bulunarak çocukla ya da eğitimiyle ilgili karar verme süreci olarak açıklanabilir.

Erken çocukluk eğitiminde, ölçme ve değerlendirmenin çocukların doğal yaşamlarının bir parçası olarak gerçekleştirilmesi oldukça önemlidir. Çocuklardan elde edilecek ölçümlerin ev, okul ve oyun alanları gibi doğal ortamlarından toplanması geçerli ve güvenilir bilgilerin elde edilmesini sağlamaktadır. Aynı zamanda, çocukların tek bir gelişim alanının yerine tüm yönleri ile değerlendirilmesi, gelişimleri ile ilgili doğru kararların alınmasını sağlayacaktır. Çocukların tüm gelişimlerini ölçmek ve değerlendirmek için de birden fazla ölçme ve değerlendirme araç ve yaklaşımlarından yararlanmak gereklidir (Mindes, 2003; Saracho, 2015). Aynı zamanda, ölçme 
değerlendirme sürekli yapılmalı ve çocuğun öğrenmesini ve gelişmesini destekleyici olmalıdır (Gullo \& Hughes, 2011). Bu nedenle çocukların gelişimlerini değerlendirmede kullanılan farklı değerlendirme yaklaşımları mevcuttur. Genel olarak bu yaklaşımlar; formal, informal ve alternatif değerlendirme olmak üzere üç temel grupta incelenmektedir (Gullo, 2005).

\subsection{Formal Değerlendirme}

Çocuğun gelişimini değerlendirmek için önceden belirlenmiş, yapılandırılmış ve standartlaştırılmış araç ve gereçler kullanılarak yapılan işlemlere formal değerlendirme denilmektedir (Wortham \& Hardin, 2012). Bu tür değerlendirmede genellikle standart testlere atıfta bulunulmaktadır. Standart testler, planlanırken ve uygulanırken belirli yöntemleri kullanan, geçerlik ve güvenirlik çalışmaları gerçekleştirilmiş olan ölçme araçlarıdır (Ellingsen, 2016). Erken çocuklukta gelişimsel değerlendirmede yaygın olarak kullanılan standart testler arasinda WISC-R, AGTE, Frostig Görsel Algı testi gibi araçlar yer almaktadır. İşlevlerine göre formal değerlendirme araçları "gelişimsel tarama testleri, tanılayıcı testler, hazır bulunuşluk testleri, başarı ve yetenek testi" olmak üzere beş temel grupta ele alınmaktadır (Bredekamp, 2015; Gullo, 2005; McAfee \& Leong, 2012).

Gelişimsel tarama testleri (developmental screening), çocukların gelişim özelliklerini, öğrenme problemlerini ya da yetersizliklerini belirlemede tüm çocuklara uygulanabilen testleri kapsamaktadır (Wright, 2010). Yaygın olarak kullanılan gelişimsel tarama testlerine; Ankara Gelişim Tarama Envanteri, Gazi Erken Çocukluk Değerlendirme Aracı, Marmara Gelişim Ölçeği, Denver II Gelişimsel Tarama Testi örnek olarak verilebilir. Tarama testleri ile çocukların gelişimleri norma ya da ölçüte bağlı olarak değerlendirilmektedir. Yani gelişimsel tarama testi bir kum eleğine benzetilirse, kum taneciklerinin çoğu elekten geçecek ve elekten geçemeyen az sayıdaki kum taneciği de daha ayrıntılı şekilde araştırılacaktır (Bredekamp, 2015). Eğer çocuk gelişimsel tarama testlerinde yaşıtlarından farklılık gösterirse ikinci aşama olarak tanılayıcı testlerden yararlanılmaktadır. Tanılayıcı testler (diagnostic), çocuğun gelişimsel ve akademik alanlardaki güçlü ya da yetersiz yönlerini saptamak ve müdahale planları hazırlamak amacıyla geliştirilmiş kapsamlı değerlendirmeleri içeren araçlardır (Gullo, 2005). Bu testleri uygulamak ve yorumlamak özel bir eğitim gerektirmektedir ve bunun için bu testlerin uygulaması genellikle bu araçların kullanımı ile ilgili eğitim almış kişiler tarafından yapılmaktadır. Peabody Resim Kelime Testi, Gessell, Bayley Testi gibi araçlar erken çocukluk döneminde kullanılan tanılayıcı testlerdendir (Wright, 2010).

Diğer bir standart değerlendirme aracı olan hazırbulunuşluk testleri (readiness test) çocukların ilkokul hazırlık derecesini belirlemek için kullanılmaktadır (Maxwell \& Clifford, 2004). Bu testler ile genellikle çocukların okul için gerekli olan ön öğrenme düzeylerini belirlenmekte ve bu öğrenme düzeyine göre okula hazır olma ile ilgili karar verilmektedir. Ülkemizde, Metropolitan Okul Olgunluğu ve Brainline Okula Hazırbulunuşluk Testi bu amaçla kullanılmaktadır. Başarı testleri (achievement test) ise çocukların okullarda genel olarak ya da özelleşmiş alanlarda neler öğrendiklerinin ölçme ve değerlendirme amacıyla uygulanmaktadır. Test maddeleri özel belirlenen bir alan için öğrenilmesi gereken bilgileri kapsamaktadır ve maddeler alanla ilgili öğretim programı ve ders kitapları temel alınarak hazırlanmaktadır. Ülkemizde erken çocukluk eğitiminde kullanımları sınırlıdır, diğer ülkelerde Stanford Erken Okul Başarı Testi, Lowa Temel 
Beceriler Testi gibi testler erken çocukluk eğitiminde yaygın olarak kullanılmaktadır. Son olarak, çocukların belirli bir alan ya da meslek için gelecekteki performans ve başarı düzeyini yordamak amacıyla geliştirilmiş yetenek testleri (ability test) alanda kullanılmaktadır (McAfee \& Leong, 2012). Bu dönem çocukları için Erken Matematik Yeteneği Testi II, McCarthy Çocuk Yetenekleri Ölçeği gibi testler örnek olarak verilebilir. Yetenek testlerinin erken çocukluk döneminde uygulanması yüksek bir yordayıcılık göstermemelerinden dolayı tartışılmaktadır (Bredekamp, 2015).

\section{2. İnformal Değerlendirme}

Görüşme, gözlem, derecelendirme ölçekleri, rubrik ve etkinlik örnekleri gibi standart olmayan teknikler kullanılarak yapılan ölçme ve değerlendirmeyi kapsamaktadır. Öğretmen gün içerisinde çocukların gelişimlerini değerlendirmek ve eğitsel kararları almak için bu teknikleri kullanmaktadır (McAfee \& Leong, 2012). İnformal değerlendirme ile çocukların gelişim ve öğrenme süreçleri değerlendirilmektedir. Örneğin, formal değerlendirme araçlarından AGTE kullanıldığında, çocuğun aldığı puana göre gelişimi hakkında norma bağlı olarak "normal gelişim düzeyinin altında" gibi sonuca odaklı bir karar verilmektedir. İnformal değerlendirmede ise çocuk gözlemlerine dayalı olarak eğitim süreci içerisinde çocuğun geldiği durum tanımlanarak "arkadaşları ile oyuncaklarını paylaşır” gibi çocuğun davranışı gözlenmekte ve bu değerlendirmeye dayalı eğitsel kararlar alınmaktadır. Sıklıkla çocuğun gelişimi, eğitim süreci içinde kendi performansı ile kıyaslanmaktadır.

\subsubsection{Görüșme}

Görüşme, en az iki kişi arasında belli bir amaç doğrultusunda gerçekleştirilen, genellikle doğrudan gözlemleyemediğimiz davranışları, durumları, duyguları ya da bakış açılarını ögrenmek için yapılan sohbet olarak tanımlanabilir (Glesne, 2014; Patton, 2014). Erken çocukluk döneminde kullanılan görüşme ise, öğretmenin çocuğu tanıma ve değerlendirmek amacıyla çocuktan ya da aileden bilgi alması temeline dayanmaktadır (Ünüvar, 2016).

Görüşmeler, görüşülen kişi sayısına, planlanmış olup olmamasına göre farklı kategorilere ayrılmaktadır. Kişi sayısına göre; bireysel ya da grup görüşmeleri yapılırken, planlamasına göre; yapılandırılmış, yarı yapılandırılmış ya da yapılandırılmamış olarak yapılmaktadır (Dinç, 2011). Bireysel görüşmeler, erken çocukluk dönemindeki çocuk ya da ailesi ile birebir gerçekleştirilen görüşmeleri kapsamaktadır. Grup görüşmelerinde ise öğretmen çocukları tanımak amacıyla görüşme yaparken, tek çocuk yerine küçük veya büyük grup halinde görüşmeyi gerçekleştirmektedir. Bu aşamada çocukların birbiri arasındaki iletişimde öğretmen için önemli bir veri kaynağı olmaktadır (Ünüvar, 2014). Yapılandırılmış görüşmelerde sorular ve görüşmenin uygulama aşaması önceden düşünülerek hazırlanılmıştır. Bu tip görüşmelerde izlenecek yolun ayrıntılı olarak düşünülmüş olması görüşmeyi yapan bireye kolaylık sağlarken, görüşme sorularının ve sürecin planlanmış olması süreç dışına çok çıkılamaması görüşmeciyi sınırlamaktadır (Erözkan, 2014; Özgüven, 2002). Yarı yapılandırılmış görüşmeler, hem yapılandırılmış görüşmedeki gibi önceden hazırlanan soruları hem de ilgili alanda derinlemesine sorgulayabilmeyi içermektedir. $\mathrm{Bu}$ yönüyle yarı yapılandırılmamış görüşme; yapılandırılmamış ve yapılandırılmış görüşmenin avantaj ve dezavantajlarını içermektedir (Büyüköztürk, Kılıç Çakmak, Akgün, Karadeniz \& Demirel, 2015). Yapılandırılmamış görüşme ise kural ve işlem aşamaları daha esnek olan, diğer görüşme 
türlerine göre daha esnek olan görüşme türüdür. Bu yöntemde açık uçlu sorular aracılığıyla zengin ve yeterli bilginin toplanması amaçlanmaktadır (Özgüven, 2002; Ünüvar, 2014). Piaget'in çalışmalarında kullandığı yapılandırılmamış görüşme (klinik görüşme) çocuklardan derinlemesine bilgi toplama imkânı sağlamaktadır (Berk, 2013).

Görüşme süreci; görüşmelerin planlanması, yapılması ve kaydedilerek çözümlenmesi aşamalarından oluşmaktadır. $\mathrm{Bu}$ aşamaların düzenli bir biçimde yapılması ve gereklerinin yerine getirilmesi görüşmenin önemli unsuru olan görüşmeciyi de rahatlatacak ve amacına uygun bilgiler almasını sağlayacaktır (Dinç, 2011). Erken çocukluk döneminde çocuk ile görüşmeye başlarken çocuğun kendisini güvende hissetmesi önemlidir. Öğretmen, görüşme sırasında güler yüzlü olmalı ve çocuğa kendini farklı hissettirecek davranışlarda bulunmamalıdır (Ünüvar, 2014). Ayrıca çocuk ile yapılacak görüşmelerde; görüşmenin oyunlaştırılması daha sağlıklı bilgiler elde edebilmek için yararlı olmaktadır. Görüşmeler; not tutma, video kaydı, ses kaydı gibi amaca göre farklı şekillerde kaydedilebilir. Daha sonra görüşmelerin anlamlandırılabilmesi için çözümlenmesi gerekmektedir. Görüşmelerin çözümlenmesinde öğretmenin elde ettiği bilgiyi hangi amaçla kullanacağına ve görüşme türüne göre bir yöntem seçilmelidir. Erken çocukluk eğitiminde görüşme raporları sıklıkla çocukların portfolyolarına eklenmektedir (Dinç, 2011).

\subsubsection{Gözlem}

Çocukları ölçme ve değerlendirmede, en yaygın ve etkili olarak kullanılan informal tekniklerden birisi gözlemdir. Gözlem çeşitli araştırmacılar tarafından farklı şekillerde tanımlanmıştır. Örneğin Mindes (2003) çocukları izleyerek onlar hakkında bilgi edinmede kullanılan sistematik bir araç olarak tanımlarken, Özgüven (2002; ss.178) ise gözlemi "belirli bir amaç için bir nesne, olay veya ilişkinin, doğal koşullarda kendiliğinden olayın belirdiği sırada, ya da bilinçli ve planlı olarak hazırlanan deney koşullarında sistematik olarak incelenmesi süreci" olarak belirtmiştir.

Gözlem genellikle, sadece görme duyusuna bağlı olarak bilgi toplama olarak düşünülmektedir. Fakat gözlemde görme duyusunun yanı sıra diğer duyuların da beraber kullanıldı̆̆ görülmektedir (Ceyhan, 2011). Başka bir ifade ile gözlem bir kimsenin, başka bir kimse hakkında duyu organları ile bilgi edinme yolu olarak da ifade edilebilir (Yıldırım \& Şimşek, 2013). Gözlemin erken çocukluk döneminde kullanım amacı, çocukların gelişimlerini izleme ve değerlendirme, eğitsel uygulamalarla ilgili planlamalar yapma, karar verme ve bu toplanan bilgileri kaydetme olarak belirtilebilir (Bredekamp, 2015).

Gözlemin, ölçme ve değerlendirme amacıyla kullanmak için gözlemin kayıt altına alınması gerekmektedir. Gözlemin amacına göre çeşitli şekillerde gözlem kayıtları tutulabilmektedir. Gözlem, genel olarak planlı şekilde yapılıp yapılmamasına göre gelişigüzel gözlem ve sistematik gözlem olarak ikiye ayrılmaktadır (Ceyhan, 2011). Gelişigüzel gözlemde bilgiler neyin, nerede, nasıl, ne zaman gözleneceğine ilişkin bir planın yapılmadığı, amacın saptanmadığı doğal bir ortamda elde edilmektedir (Erözkan, 2014). Ölçme ve değerlendirme amacı ile yapılan sistematik gözlemlerde ise gözlemin amacı ve odağı belirlenmekte detaylar ve davranışlar mümkün olduğunca nesnel olarak kaydedilmektedir. Gözlenen davranışlara ait değerlendirme ve yorumlar gözlem notlarından ayrı bir șekilde belirtilmektedir. Son olarak, tek bir gözleme dayalı bir karara ulaşmak yerine tekrarlı gözlemler sonucunda çocukla ilgili karar verilmektedir. $\mathrm{Bu}$ 
sayede, gözlemin doğruluğu ve güvenilir olması sağlanmaktadır (Erözkan, 2014; McAfee \& Leong, 2012; Özgüven, 2002; Wodarski, 2015).

Erken çocukluk eğitiminde yaygın olarak kullanılan gözlem teknikleri arasında serbest gözlem, anekdot, kontrol listeleri, derecelendirme ölçekleri gibi araçlar yer almaktadır. McAfee \& Leong (2012) gözlem kayıt tekniklerini açıklayıcı, hesaplama ve sınıflama teknikleri olarak üç temel grupta incelemiştir (bknz. Tablo 1). Açıklayıcı kayıtlar, davranışın genel bir resmini çekerken, hesaplama teknikleri davranışın kaç kez yapıldığını göstermektedir. Sınıflama ve derecelendirme teknikleri ise diğer bireylere ve önceden belirlenmiş standartlara göre bir sıralama ve derecelendirme amaciyla kullanılmaktadır (McAfee \& Leong, 2012).

Tablo 1.

Gözlem Kayıt Teknikleri

\begin{tabular}{|c|c|}
\hline & Kayıt Teknikleri \\
\hline Açıklayıcı & $\begin{array}{l}\text { Açıklayıcı anlatılar, anekdot kayıtları, kısa notlar, } \\
\text { şekiller/grafikler, taslaklar, fotoğraflar, işitsel ve } \\
\text { görsel kayıtlar }\end{array}$ \\
\hline Hesaplama & $\begin{array}{l}\text { Kontrol listeleri, katılım grafikleri, frekans tabloları } \\
\text { (süre kaydı, olay kaydı) }\end{array}$ \\
\hline Sinıflama ve Derecelendirme & Derecelendirme ölçekleri, rubrikler \\
\hline
\end{tabular}

Kaynak: McAfee \& Leong, 2012

Açıklayıcı kayıt tekniklerinde, gözlenen olaylar detaylı ve öykü tarzında kaydedilir. Bu tekniklerden anekdot kayıtları, bir ya da birden çok çocuğun dahil olduğu ortamda, çocuğun davranışlarında görülen önemli gelişimsel olayları kaydetmek amacıyla kullanılır (Bredekamp, 2015; Mindes, 2003). Anekdot kaydı tutulurken; davranışın direkt gözlem sonucu olmasına, öğretmen yorumunun ayrı bir bölümde yer almasına ve tek bir olayı açıklamasına dikkat edilmelidir (Gullo, 2005). Ayrıca, anekdot kayıtlarında çocuğun gelişimsel özellikleri ve program amaçlarını kazanıp kazanmadıklarını içeren davranışlar da not edilmektedir (Mindes, 2003). Tablo 2.'de altı yaşında bir erkek çocuğun bilişsel gelişimi ile ilgili örnek anekdot kaydı yer almaktadır.

Tablo 2.

Anekdot Kaydı Örnĕgi

Çocuğun Adı/Yaşı: Ali/ $6 \quad$ Gözlem Tarihi: 04.04.2015

Gözlenen mekân ve çocuk grubu: Masa oyuncakları merkezi- bireysel oyun

Gözlenen durum: Ali, masa oyuncakları merkezinde çok sayıda düğmenin olduğu kutuyu aldı ve masaya oturdu. Düğmeleri renklerine ve boyutlarına göre sinıflandırdı. Düğmelerin hepsini karıştırıp tekrar ayırdı ve "küçük ve kırmızı düğmeleri, büyük ve kırmızı düğmeleri ayırdım” dedi.

Yorumlar: Ali daha önce nesneleri renklerine göre sınıflandıramamıştı. Ali’ye farklı boyutlarda ve şekillerde düğmeler verilerek sınıflandırma becerisine yönelik ilgisi devam ettirilebilir.

Açıklayıcı teknikler arasında yer alan serbest gözlem, not tutma ya da anlatı kaydı (running record) olarak bilinen gözlemde ise gözlenen davranış veya olay anekdot ve detaylı olarak anlatılır. Anlatı kayıtları ile anekdot kayıtları arasındaki temel fark anekdot kayıtları, davranışın ya da olayın belirli bir bölümünü kısa şekilde açıklarken, anlatı kayıtları tüm yönleriyle, sanki bir videoya çekilmiş gibi davranışları açıklamaktadır. Bu 
amaçla yapılan gözlemlerde, söylenen ve yapılan tüm davranışlar ile ortam ayrıntılı şekilde kayıt altına alınmaktadır. Çok ayrıntılı bir şekilde not tutulduğu için öğretmenler tarafından daha az kullanılmaktadır (Gullo, 2005; McAfee \& Leong, 2012). Örnek anlatı kaydı Tablo 3.'te yer almaktadır.

Tablo 3.

Anlatı Kaydı Formu Örneği

\begin{tabular}{|c|c|c|}
\hline İsim: Ali Se & & Tarih: 10.02 .2015 \\
\hline Süre & Notlar & Yorum \\
\hline 09.00-09.10 & $\begin{array}{l}\text { Ali sınıfa girip hemen blok köşesine yöneldi. } \\
\text { Büyük blokları tek tek raftan indirdi. } 4 \text { tane } \\
\text { bloğu yan yana dizdi. Bunların üzerine raftan } \\
\text { aldığı diğer blokları yerleştirdi. } \quad \text { Hiç } \\
\text { konuşmadan blokları üst üste dizmeye devam } \\
\text { etti. }\end{array}$ & $\begin{array}{l}\text { Bloklarla bir şey } \\
\text { yaparken çok iyi } \\
\text { konsantre oluyor. } \\
\text { Blokları becerikli bir } \\
\text { şekilde kullanıyor. }\end{array}$ \\
\hline 09.20-09.30 & $\begin{array}{l}\text { Ali bloklardan büyük bir ev yaptı. Büyük } \\
\text { bloklarla yaptığı birinci katın üzerine küçük } \\
\text { blokla da ikinci ve üçüncü katları inşa etti. Evin } \\
\text { pencereleri için boşluklar oluşturdu. Çatı için ise } \\
\text { küçük bloklar kullandı }\end{array}$ & \\
\hline 09.40-09.50 & $\begin{array}{l}\text { Yaptığı evi tamamladı ve okula yeni gelen } \\
\text { Ahmet'i çağırdı. "Bak yaptı̆̆ım eve" dedi. } \\
\text { Ahmet, "güzel olmuş" dedi. "Hadi bir şeyler } \\
\text { daha yapalım, Sen de evin yanına garaj yap, } \\
\text { arabalarımızı koyalım," dedi. Ali büyük bir } \\
\text { blok aldı ve Ahmet'e verdi. "Bunu al duvar } \\
\text { yapalım," dedi. Ali tek tek blokları Ahmet'e } \\
\text { verdi ve ne yapacağını söyledi. Birlikte garajı } \\
\text { tamamladılar. Ali, "git araba getir, garajın içine } \\
\text { koyalım," dedi. }\end{array}$ & $\begin{array}{l}\text { Liderlik yönü çok } \\
\text { kuvvetli, özellikle yakın } \\
\text { arkadaş1 Ahmet'i } \\
\text { yönlendiriyor. }\end{array}$ \\
\hline
\end{tabular}

Hesaplama teknikleri, gözlenen davranışın süresi, sayısı ve sıklığı hakkındaki bilgileri içeren kayıtlardır. Bu tekniklerde çocuklarda gözlenmek istenilen davranışlar önceden belirlenir, uygun form hazırlanır ve sadece bu formda belirtilen davranışların ne sıklıkla görüldüğü veya ne kadar süre ile devam ettiği kaydedilir (McAfee \& Leong, 2012). Davranışın sıklığını belirlemek için sıklık kaydından, davranışın süresini belirlemek için ise süre kaydından yararlanılmaktadır (Bknz. Tablo 4. ve 5.). Bu sayede öğretmenler, çocukta bulunan davranışın gelişimsel olarak uygun özellikte olup olmadığını tespit etmekte ve eğer farklılık olduğunu gözlemlerlerse daha ayrıntılı inceleme için anekdot kayıtlarından yararlanmaktadırlar. Bu teknikler genellikle bir davranışın sıklığını arttırmak ya da azaltmak amacıyla kullanılmaktadır. 
Tablo 4.

Siklık Kaydı Formu Örneği

Amaç: Çocukların Türkçe-dil etkinliğine olumlu ve olumsuz katılımlarının belirlenmesi

Sinıf: Kardelen anasınıfi

Tarih: 09.02 .2015

Gözleyen: Ayşe Yavaş

Gözlenen davranış: Olumlu / Olumsuz katılım

Süre: $10.00-10.30$ Türkçe etkinliği

Kod: Olumlu katılım (O) ilgili sorular sorma, cevap verme, yorum yapma, dinleme

Olumsuz katılım (M) ilgisiz soru sorma, konuşma, yerinde durmama,

ilgilenmeme, başka çocukları rahatsız etme

\begin{tabular}{lllllllll}
\hline \multirow{2}{*}{ Cocuklar } & \multicolumn{2}{l}{ Hikâye öncesi } & \multicolumn{2}{l}{ Hikâye anlatma } & \multicolumn{2}{l}{ Hikâye sonrası } & & \\
\cline { 2 - 10 } & O & M & O & M & O & M & T O & T M \\
\hline Ahmet & II & & III & & II & & 7 & 0 \\
\hline Ayşe & & II & & IIII & I & II & 1 & 8 \\
\hline Elif & IIII & I & II & I & II & & 8 & 2 \\
\hline Kemal & IIII & I & I & & IIII & I & 10 & 2 \\
\hline Can & III & IIII & I & IIII & & IIII & 4 & 13 \\
\hline Dilara & III & & I & & I & & 5 & 0 \\
\hline Oya & II & IIII & I & & I & III & 4 & 7 \\
\hline Fatma & II & I & I & I & I & I & 4 & 3 \\
\hline Ezgi & III & I & II & I & II & I & 7 & 3 \\
\hline Toplam & 24 & 14 & 12 & 12 & 14 & 12 & &
\end{tabular}

Yorum: Hikâye öncesi etkinliklerde çocukların olumlu katılımları en iyi düzeydedir.

Kemal, Elif, Ahmet ve Ezgi en fazla olumlu katılım gösteren çocuklardır. Can, Ayşe ve Oya en fazla olumsuz katılım gösteren çocuklardır. Dilara ve Fatma ise etkinliğe en az katılım gösteren çocuklardır.

Tablo 5.

Süre Kaydı Formu Örneği

Gözlenen: Mert Kaya

Gözlenen Davranış: Çocuğun evdeki etkinlik seçimi

Ön Uyaran: Oyun materyallerinin çocuğun görüp ulaşabileceği yerde olması

Tarih: 15.08 .2015

\begin{tabular}{cccccc}
\hline Süre & Kitap & Resim & TV & Araba & Lego \\
\hline $\mathbf{1 4 . 0 0 - 1 4 . 1 5}$ & $4 \mathrm{dk}$ & $5 \mathrm{dk}$ & $3 \mathrm{dk}$ & $1 \mathrm{dk}$ & $2 \mathrm{dk}$ \\
\hline $\mathbf{1 4 . 1 5 - 1 4 . 3 0}$ & & & & $8 \mathrm{dk}$ & $7 \mathrm{dk}$ \\
\hline $\mathbf{1 4 . 3 0 - 1 4 . 4 5}$ & & $10 \mathrm{dk}$ & & $5 \mathrm{dk}$ & \\
\hline $\mathbf{1 4 . 4 5 - 1 5 . 0 0}$ & $5 \mathrm{dk}$ & & $9 \mathrm{dk}$ & $1 \mathrm{dk}$ & \\
\hline $\mathbf{1 5 . 0 0 - 1 5 . 1 5}$ & $8 \mathrm{dk}$ & & $2 \mathrm{dk}$ & & $5 \mathrm{dk}$ \\
\hline $\mathbf{1 5 . 1 5 - 1 5 . 3 0}$ & $2 \mathrm{dk}$ & $5 \mathrm{dk}$ & & & $8 \mathrm{dk}$ \\
\hline $\mathbf{1 5 . 3 0 - 1 5 . 4 5}$ & & $4 \mathrm{dk}$ & $3 \mathrm{dk}$ & $8 \mathrm{dk}$ & \\
\hline $\mathbf{1 5 . 4 5 - 1 6 . 0 0}$ & $6 \mathrm{dk}$ & & & & $9 \mathrm{dk}$ \\
\hline Toplam & $25 \mathrm{dk}$ & $24 \mathrm{dk}$ & $17 \mathrm{dk}$ & $23 \mathrm{dk}$ & $31 \mathrm{dk}$ \\
\hline
\end{tabular}

Hesaplama tekniklerinden bir diğeri ise kontrol listeleridir. Çocukların davranışlarının, becerilerinin ve tutumlarının hakkında bilgi toplamanın pratik ve çok yönlü araçları olarak kullanılmaktadır. Kontrol listeleri geliştirilirken, standartlar, öğretim hedefleri 
veya gelişim aşamaları göz önünde bulundurulmaktadır (McAfee \& Leong, 2012). Geliştirilen kontrol listeleri; gelişim özellikleri davranışsal kategorileri, sosyal/duygusal davranışları, ilgi alanları, belirli akademik yetenekleri, belirli kavram ve bilgileri içermektedir (Gullo, 2005). Bazı kontrol listeleri çocukların gerçekleştirdikleri davranışlara ilişkin "evet"-"hayır" şeklinde doldurulurken, bazıları da öğretmenin çocuğun yaptığı bir beceriyi ne derecede kazandığını belirlemesi ve yargıda bulunmasını sağlayacak şekilde düzenlenmektedir. Eğer kontrol listeleri iyi tasarlanıp, uygun şekilde kullanılabilirlerse çocukların gelişimin anlayıp onlara rehber olabilmek ve uygun programı geliştirebilmek daha kolay olacaktır. Kontrol listelerinin güçlü yönünü, davranışı kayıt altına almanın hem süre hem de uğraş açısından kolay olması, zayıf yönü ise çocukların yeterliliğini tüm karmaşıklığı ortaya koyamaması oluşturmaktadır (Bredekamp, 2015; Gullo, 2005).

\section{Tablo 6.}

Kontrol Listesi Formu Örneği

Çocuğun Adı: Mehmet Kara

$$
\text { Duygusal Alan Gelişim Kontrol Listesi }
$$

\begin{tabular}{lcc}
\hline & Evet & Hayır \\
\hline Duygularını adlandırır & $\sqrt{ }$ & \\
\hline Başkalarının duygularını anlar & & $\sqrt{ }$ \\
\hline Duygularının nedenlerini söyler. & & $\sqrt{ }$ \\
\hline
\end{tabular}

Sınıflama ve derecelendirme teknikleri, standartlar veya diğer kişilere göre belirli bir puan aralığında ne konumda olunduğuna ilişkin kararları içeren ve bu kararların kaydedilmesini sağlayan tekniklerdir (McAfee \& Leong, 2012). Bu araçlardan biri olan derecelendirme ölçekleri (Bkz. Tablo 7.), çocuklarda mevcut olduğuna inanılan davranışların derecesini tespit edebilmek için kullanılmaktadır (Mindes, 2003). Ölçekte davranışın düzeyleri kelime (örneğin; asla, nadiren, bazen, sıklıkla gibi) ya da rakamlarla (örneğin; 1: yeterli değil,....., 5: iyi gibi) belirtilmektedir. Hızlı bir biçimde gözlemlerin kayıt edilmesi, gözlemciler arasında tutarlılı̆̆ı kolayca sağlanması, çocukların gelişimini izlemeyi kolaylaştırması derecelendirme ölçeklerinin güçlü yönünü oluşturmaktadır. Derecelendirme ölçeklerinin zayıf yönünü ise, nitelikli derecelendirme ölçeği oluşturmanın zor bir süreç olması oluşturmaktadır (Kumtepe, 2011).

Tablo 7.

Derecelendirme Ölçeği Örneği

Çocuğun Adı/Yaşı: Mert Kaya/ 2

Tarih: 24.04.2015

Gözlemci: Berrin Aksekili

1= Hiçbir zaman 2= Nadiren 3= Bazen 4= Sik sik 5= Her zaman

\begin{tabular}{|c|c|c|c|c|}
\hline BİLİŞSEL GELİ̧i̇M & 1 & 23 & 4 & 5 \\
\hline Nesneleri, aynı nesnelerin resimleri ile eşleştirebilir. & & & $\mathbf{X}$ & \\
\hline Bazı renkleri ayırt edebilir.(sarı, kırmızı, mor) & & & $\mathbf{X}$ & \\
\hline Tanıdığı nesneler için sorulan "Bu ne?" sorusuna cevap verir. & & & $\mathbf{X}$ & \\
\hline Basit soruları anlar. & & & & $\mathbf{X}$ \\
\hline $\begin{array}{l}\text { Ertelenmiş taklit yapar. } \\
\text {. }\end{array}$ & & & & $\mathbf{X}$ \\
\hline
\end{tabular}

Rubrikler ise karmaşık performansların değerlendirilmesine olanak sağlayan ölçekteki her puan ya da derecelendirme ile ilgili açı yönergelere sahip olan betimleyici ölçeklerdir (McAfee \& Leong, 2012). Alanda holistik, analitik ve gelişimsel rubrik olmak 
üzere üç tür rubrik kullanılmaktadır. Holistik rubrikte performansın bütününe puan verilerek değerlendirme yapılmaktadır. Performansın derecesi yetkinlik düzeyine göre belirlenmektedir (Wright, 2010). Performansın oluşmasında tek bir doğrunun olmadığg durumlarda kullanılması daha uygundur. Örneğin, konuşma performansının değerlendirilmesinde holistik rubrik kullanılabilmektedir (bknz. Tablo 8.).

Tablo 8.

Holistik Rubrik Örneği

Çocuğun Adı Soyadı: Merve Can

Tarih: 23.05.2015

Performans Kendini ifade edebilme

\begin{tabular}{cclccc}
$\begin{array}{c}1 \\
\text { (Başarısız) }\end{array}$ & $\begin{array}{c}2 \\
\text { (Başlangıç) }\end{array}$ & $\begin{array}{c}\text { 3 } \\
\text { (Gelişmekte) }\end{array}$ & $\begin{array}{c}\text { Gä̧arı } \\
\text { (Başarı̈ı̆ı̧ı) } \\
\text { Düzeyi }\end{array}$ & $\begin{array}{c}\text { ve } \\
\text { Öneriler }\end{array}$ \\
\hline
\end{tabular}

Bir konuda

konuşma

başlatamaz ve

başlatılan bir

konuda

konuşmakta

zorlanir.

Görüșünü açık bir iletir

Bir konuda

konuşmayı

başlatır fakat

sürdürmekte

zorlanır.

biçimde iletemez.

Bir konuda

Bir konuda konuşmayı

konuşmayı başlatarak

sürdürür ve

sürdürür ve görüşünü açık

görüsünü açk bir biçimde

bir biçimde

iletir.

Görüşünü

desteklemek

için yaratıcı

örnekler verir.

Kaynak: Kumtepe, A. T. (2011). Çocukları tanıma teknikleri. Eskişehir: Anadolu Üniversitesi Yayınları'ndan yararlanılarak oluşturulmuştur.

Diğer rubrik türü olan analitik rubrik, performansın ayrıntılandırılabildiği, ayrı ayrı basamaklardan oluştuğu durumlar için tercih edilmektedir. Ayrılan her bir parçanın puanlanması ve bu puanlardan toplam puan edilmesi esasına dayanmaktadır. Çocuğun sosyal beceri ile ilgili ile uyması gereken ölçütlere dayandırılmış ve maddeleri buna göre düzenlenip puanlanmış bir değerlendirme aracı analitik rubriğe örnek olarak gösterilebilir (bknz. Tablo 9.). 


\begin{tabular}{|c|c|c|c|c|c|}
\hline \multicolumn{6}{|c|}{$\begin{array}{l}\text { Tablo 9. } \\
\text { Analitik Rubrik Örneği } \\
\text { Çocuğun Adı Soyadı: Büşra Can } \\
\text { Tarih: } 11.03 .2015\end{array}$} \\
\hline Ölçütler & $\begin{array}{l}\text { Başlangıç } \\
\text { Düzeyinde (1) }\end{array}$ & $\begin{array}{l}\text { Kabul Edilebilir } \\
\text { (2) }\end{array}$ & Başarılı (3) & $\begin{array}{l}\text { Başarı } \\
\text { Düzeyi }\end{array}$ & $\begin{array}{l}\text { Görüss } \\
\text { öneriler }\end{array}$ \\
\hline $\begin{array}{l}\text { Doğru/ } \\
\text { Yanlış } \\
\text { Davranışı } \\
\text { Ayırt Etme }\end{array}$ & $\begin{array}{l}\text { Etkinlikte geçen } \\
\text { doğru ya da } \\
\text { yanlış } \\
\text { davranışların çok } \\
\text { azını } \\
\text { belirlemiştir. }\end{array}$ & $\begin{array}{l}\text { Etkinlikte geçen } \\
\text { doğru ya da } \\
\text { yanlış } \\
\text { x davranışların } \\
\text { çoğunu } \\
\text { belirlemiştir. }\end{array}$ & $\begin{array}{l}\text { Etkinlikte geçen } \\
\text { doğru ya da yanlış } \\
\text { davranışların } \\
\text { tümünü } \\
\text { belirlemiştir. }\end{array}$ & & \\
\hline $\begin{array}{l}\text { Hatayı } \\
\text { Kabul } \\
\text { Etme }\end{array}$ & $\begin{array}{l}\text { Hata } \\
\text { yapıldığında, } \\
\text { hatanın kabul } \\
\text { edilmesi } \\
\text { gerektiği fikrini } \\
\text { neredeyse hiç } \\
\text { söylememiştir. }\end{array}$ & $\begin{array}{l}\text { Hata } \\
\text { yapıldığında, } \\
\text { hatanın kabul } \\
\text { edilmesi gerektiğ } \\
\text { fikrini genel } \\
\text { olarak } \\
\text { söylemiştir. }\end{array}$ & $\begin{array}{l}\text { Hata yapıldığında, } \\
\text { hatanın kabul } \\
\text { i edilmesi gerektiği } \\
\text { fikrini hemen } \\
\text { söylemiştir }\end{array}$ & & \\
\hline $\begin{array}{l}\text { Hatayı } \\
\text { Söyleme }\end{array}$ & $\begin{array}{l}\text { Yapılan hatayı } \\
\text { ve nasıl } \\
\text { olduğunu } \\
\text { (Ali’nin vazoyu } \\
\text { kırması) } \\
\text { neredeyse hiç } \\
\text { söylememiştir. }\end{array}$ & $\begin{array}{l}\text { Yapılan hatayı ve } \\
\text { nasıl olduğunu } \\
\text { (Ali’nin vazoyu } \\
\text { kırması) genel } \\
\text { olarak söylemişti }\end{array}$ & $\begin{array}{l}\text { Yapılan hatayı ve } \\
\text { nasıl olduğunu } \\
\text { (Ali’nin vazoyu } \\
\text { kırması) ayrıntılı } \\
\text { rolarak söylemiştir }\end{array}$ & & \\
\hline $\begin{array}{l}\text { Hataya } \\
\text { Çözüm } \\
\text { Önerme }\end{array}$ & $\begin{array}{l}\text { Yapılan hataya } \\
\text { (Ali'nin vazoyu } \\
\text { kırması) } \\
\text { neredeyse hiç } \\
\text { çözüm } \\
\text { üretmemiştir }\end{array}$ & $\begin{array}{l}\text { Yapılan hataya } \\
\text { (Ali’nin vazoyu } \\
\text { kırması) genel } \\
\text { olarak çözüm } \\
\text { üretmiştir. }\end{array}$ & $\begin{array}{l}\text { Yapılan hataya } \\
\text { (Ali'nin vazoyu } \\
\text { kırması) hemen } \\
\text { çözüm üretmiştir } \\
\text { (harçlıklarından } \\
\text { vazo alacağını } \\
\text { söylemesi gibi). }\end{array}$ & & \\
\hline
\end{tabular}

\section{Öğretmen Değerlendirmesi ve Geribildirim:}

Kaynak: Ömeroğlu, E., Büyüköztürk, Ş., Aydoğan, Y., Çakan, M., Özyürek, A., Gültekin Akduman, G. vd. (2014). Okul öncesi çocuklar için sosyal beceri destek eğitimi öğretmen rehber kitabı (OSBEP)'den yararlanılmıştır.

Gelişimsel rubrikte ise bir performansın aynı yaş düzeyinde tüm çocuklar tarafından aynı şekilde gerçekleştirilememesinden dolayı değerlendirmenin gelişimsel bir süreç olarak rubrikte gösterilmesi gerektiği vurgulanmaktadır. Bunun için gelişimsel rubrik birden fazla yaş seviyesini kapsayabilir nitelikte hazırlanabilmekte ve süreç içerisinde çocuğun bu ölçeğe göre değerlendirilmesini sağlamaktadır. Hazırlanmasında ise çocuğun bu yeteneği, farklı seviye ve yaşlarda hazırlanan rubrik kullanılarak değerlendirilecektir varsayımı vardır (Gullo, 2005). Çocuğun psikomotor becerileri ile ilgili maddeleri aşamalı olarak düzenlenip puanlanmış bir değerlendirme aracı gelişimsel rubriğe örnek olarak gösterilebilir (bknz. Tablo 10.). 
Tablo 10.

Gelişimsel Rubrik Örneği

Çocuğun Adı Soyadı: Betül Can

Tarih: 04.08.2015

$\begin{array}{llllll}\begin{array}{l}\text { Ölçütlerin } \\ \text { Üstünde (4) }\end{array} & \text { Yeterli (3) } & \begin{array}{l}\text { Kısmen Yeterli } \\ (2)\end{array} & \text { Yetersiz (1) } & \begin{array}{l}\text { Başarı } \\ \text { Düzeyi }\end{array} & \begin{array}{l}\text { Görünş } \\ \text { ler }\end{array} \\ \end{array}$

İki tekerlekli Üç tekerlekli Üç tekerlekli Çok az pedal

bisikletleri bisikleti daha bisikleti sürebilir. çevirebilir.

destek hizlı sürer ve

tekerlekleri ile bisikleti daha

birlikte sürer. düzgün

yönlendirir.

Daha iyi şekilde Vücudunu daha Üst vücudunu çok Üst vücudu sabit

firlatma ve iyi hareket az kullanarak topu tutarak zıplar,

yakalama ettirerek ve firlatıp tutabilir; hoplar, firlatır ve

eylemin ağırlığını öne topu göğsüne yakalar.

gerçekleştirir. vererek topu doğru yakalamaya

firlatabilir; topu çalışır.

elleri ile

yakalayabilir.

Kaynak: Berk, L. E. (2013). Bebekler ve çocuklar doğum öncesinden orta çocukluğa. Ankara: Nobel Yayınevinden yararlanılarak oluşturulmuştur.

Rubrikler esnek, uyarlanabilir, çocukların performanslarına yol gösterici bir araç olması ve çok çeşitli seviyelerde kullanılabilmesi yönüyle oldukça avantajlıdır. Rubriklerin kullanımında en büyük zorluk ise öğretmenin kriter geliştirme ve kullanmada yeterli olmaması durumudur (Gullo, 2005). Rubrikler derecelendirme ölçeklerine oranla daha güvenilir kaynaklar olarak kabul edilmektedir, çünkü işaretlemek için gereken ölçütler açık olarak belirtilmiştir (Bredekamp, 2015).

\subsection{Alternatif Değerlendirme}

Alternatif değerlendirme, çocukların bilgi ve becerilerini sergileyebilecekleri gerçek ve anlamlı çalışmaları yapmalarını gerektiren bir değerlendirmedir. Alternatif değerlendirmede, çocukların gözlemlenerek, çalışma örnekleri toplanarak, oyun temelli uygulamalar yapılarak gelişim ve öğrenmeleri değerlendirilir (Colorado Department of Education [CDE], 2012; Gullo, 2005; Mindes, 2003; Riley, Miller \& Sorenson, 2016). Otantik değerlendirme ve portfolyo değerlendirme zaman zaman alternatif değerlendirme kavramı yerine kullanılabilmektedir. Ancak adlandırılmaları her ne kadar farklı olarak belirtilse de hepsinin amaçları birbirleri ile tutarlıdır. Alternatif değerlendirmede çocukların gelişimleri hakkında bilgi toplamak için gözlem ve çalışma örnekleri kullanılmaktadır (North Cenral Regional Educational Laboraty [NCREL], 1999).

Alternatif değerlendirme, sınıf ortamında yani çocukları doğal öğrenme ortamlarında gerçekçi olarak değerlendirmeyi amaçlamaktadır. Ayrıca öğretmen ve çocukların değerlendirme sürecine aktif olarak katılımını sağlamaktadır. (Gullo, 2005). Alternatif 
değerlendirme yaklaşımlarından en bilinenleri oyun temelli, dinamik, program temelli değerlendirme ve portfolyo değerlendirmesi olarak belirtilebilir.

\subsubsection{Oyun temelli değerlendirme}

Oyun temelli değerlendirme çocukların gelişim ve öğrenmelerini değerlendirmek için kullanılan geçerli ve güvenilir bir değerlendirmedir. Alanda en köklü ve yaygın kullanılan aynı zamanda, öğretmenlerinde rahatlıkla kullanabileceği bir değerlendirmedir (Bergen, 2015). Oyun temelli değerlendirme, öğretmenlerin oyun oynayan çocukları bireysel ya da grup olarak sistematik bir şekilde gözlemleyerek çocukların gelişimsel ve akademik yeterlilikleri hakkında bilgi elde etme süreci olarak tanımlanır (Gullo, 2005; Linder, 2008). Bu değerlendirmede 3-6 yaş çocukları sınıf, park veya evde gibi doğal ortamlarında değerlendirilir (Dykeman, 2008). Böylece, doğal ortamda değerlendirme en kolay şekilde oyun aracıllğı ile gerçekleşmektedir. Ayrıca, oyun temelli değerlendirme çocuklar hakkında bilgiye ilk elden ve doğrudan ulaşılmasını sağlamaktadır (Linder, 2008).

Oyun temelli değerlendirme çocukların tüm gelişim alanları ve oyunlarının niteliğinin değerlendirilmeye olanak vermektedir. Çocuk oyunda özgürce davranışlar sergilemekte ve buda öğretmene çocuğun tüm gelişim alanları ile ilgili doğrudan bilgiler sunmaktadır. Ayrıca, çocukların oyun, ortam, kullandıkları materyaller, oyun türü, oyun davranışları gibi çocukların oyuna yönelik özellikler değerlendirilmektedir (Gullo, 2005). Çocukların oyunlarının niteliği değerlendirilirken ölçüt olarak Piaget, Parten, Smilansky gibi kuramcıların oyun gelişimine yönelik tanımladıkları evreler kullanılmaktadır (Ören, 2011). Ayrıca oyun temelli değerlendirme için geliştirilmiş "TPBA" "PIECES" gibi standart oyun değerlendirme araçları alanda mevcuttur (Kelly-Vance \& Ryalls, 2014; Riley, Miller \& Sorenson, 2016).

Öğretmenin oyun temelli değerlendirme yapılabilmesi için öncelikle amacı belirlemesi gerekmektedir. Belirlenen amaca göre de gözlem yapılacak alan ve gözlemde kullanılacak yöntemler belirlenmelidir (Losardo ve Notari- Syverson, 2011). Örneğin, öğretmen çocukların sosyal gelişimlerini oyun temelli değerlendirme yoluyla saptamak istediğinde sosyal oyunların; (a) süre ve sıklık kayıtları, (b) birlikte oynadıkları arkadaşları, (c) gelişimsel rubrikle oyun sırasındaki sosyal becerileri (problem çözme, paylaşma vb.) gözlenebilir. Elde edilen bu gözlemlerle çocukların sosyal oyun nitelikleri ile ilgili kararlar verilebilir.

\subsubsection{Dinamik değerlendirme}

Dinamik değerlendirme çocukların öğrenme sürecine odaklanmakta ve öğrenme potansiyellerini değerlendirmek için kullanılmaktadır (Grigorenko \& Sternberg, 1998). Geleneksel değerlendirme çocukların öğrenme çıktılarına odaklanırken dinamik değerlendirme çocukların öğrenme süreçlerine odaklanmaktadır (Lidz, 1991). Dinamik değerlendirme kuramsal temelini Vygotsky'nin öğrenme, gelişim ve değerlendirme üzerine olan görüşlerinden almaktadır. Vygotsky'ye göre çocuğun gelişimini ve öğrenmesini desteklemek için çocuk hakkında iki düzeyi bilmek gerekmektedir. Bunlardan birincisi çocuğun yardımsız tek başına bir görevi yapabildiği düzey, ikincisi de yetişkin ya da daha yetenekli bir akran yardımıyla yapabildiği düzeydir. Bu iki düzey arasında kalan, çocuğun görevi yapabilmek için desteğe ihtiyaç duyduğu alana Yakınsal Gelişim Alanı kavramı ile açıklanmaktadır (Gullo, 2005; Geva \& Wiener, 2014). Bu temele dayalı olarak, dinamik değerlendirme süreci iki aşamadan oluşmaktadır. Birinci 
aşamayı, çocuğun yakınsal gelişim alanı içinde yer alan yani çocuğun henüz ustalaşmadığ 1 bir konuda belirlenen görevi yardım almadan yerine getirmesi oluşturmaktadır. Bu sayede çocuğun verilen görevi bağımsız olarak tamamlama düzeyi belirlenmektedir. Eğer çocuk bu aşamada verilen görevde başarılı olursa daha zor bir görev verilerek tekrar gözlem yapılmaktadır. İkinci aşamayı, çocuğun yardımla yapabildiği düzey oluşturmaktadır. Çocuğa gerekli destek sağlanarak çocuğun birinci aşamada tek başına yapmasını istediğimiz görevi öğrenmesi beklenmektedir. Böylece öğretmen çocuğa süreç sırasında ne tür bir deneyim ve destek sağlaması gerektiğine karar vermektedir. Değerlendirme sürecinde çocuğa verilen yardım; öğretmenin desteği, akran etkileşimi ya da performansı ileri düzeye çıkaran materyallerin sağlanması şeklinde yapılabilmektedir (Bodrova \& Leong, 2010).

Yukarıda da ifade edildiği gibi değerlendirme sürecinde hem öğretmen hem de çocuk aktif olarak rol almaktadır. Bu tür değerlendirmede çocuğun deneyimlerinin yanı sıra öğretmenlerin deneyimleri de değerlendirme için devreye girmekte ve çocuk bu yol ile aracılı deneyimlere sahip olmaktadır. Çocuğu değerlendiren kişi gözlemi gerçekleştirirken tarafsız bir rol üstlenmemekte, süreç boyunca çocuğun öğrenme potansiyelini belirleyebilmek için sorular sormakta ve ipuçları vermektedir. Çocuğun aynı göreve müdahaleden önce ve sonra verdiği tepki karşılaştırılmakta ve müdahaleden sonra yetişkinin gösterdiği destek miktarına, kullanılan ipucu sayısı gibi özelliklere odaklanılmaktadır (Gullo, 2005). Öğretmen erken çocukluk döneminde yapacağ 1 dinamik değerlendirme ile çocuk hakkında eğitimsel kararları da alabilmektedir. Dinamik değerlendirme yoluyla çocuğun neleri yapabildiğinin yanı sıra çocuğun ipuçlarına yönelik tepkilerini de gözlemlemektedir. Bu sayede öğretmen çocuğun belirtilen görevi yardımla nasıl gerçekleştirebildiği ve o yardımı farklı performanslara nasıl aktarabildiği ile ilgili de ayrıntılı bilgi edinebilmektedir. Belirtilen ipuçlarının yardımıyla beceri ya da kavramları o çocuk için nasıl daha iyi şekilde öğreteceğine ve nasıl destek sağlayacağına karar vermesini de sağlamaktadır (Ören, 2011).

Dinamik değerlendirmenin özellikleri özetlenecek olursa üç temel noktaya dikkat çekmek gerekmektedir. Bunlardan birincisi etkileşimli olarak doğal ortamda yapılması, ikincisi öğrenme sürecine odaklanması, son olarak da çocukların cevap verme yeteneği hakkında bilgi vermesi ve sonuçlarının müdahale programlarını desteklemesidir (Lidz, 1995). Dinamik değerlendirme en kolay olarak "test, öğret ve tekrar test et" döngüsü olarak uygulanmaktadır. Çoğu zaman öğretmen gözlemleri veya çocuklara sorulan sorular gibi informal şekilde testler yapılmaktadır. Örneğin, anaokulunda öğretmen 4 yaşındaki Mehmet'in matematik etkinliğinde rakamlarla nesneleri eşleştiremediğini 5 'ten sonra karıştırdığını gözlemler. Bu gözlemi test olarak kabul eden öğretmen Mehmet'in rakamla nesneleri eşleştirebileceği bir dizi etkinlik ve oyun hazırlar. Bu oyunları Mehmet'le birlikte oynar ve etkileşimleri sırasında gözlemlemeye devam eder. Rakamlarla ilgili ipuçlarını ona da gösterir ve bu beceride ustalaşmasına yardımcı olur. Son aşamada Mehmet'in tek başına yeniden bu becerilerini test eder ve ilk aşamayla son aşama arasındaki farkları değerlendirir. Elde edilen gözlemler ile çocuğun matematik becerileri ile ilgili kararlar verilir.

\subsubsection{Program temelli değerlendirme}

Diğer bir alternatif değerlendirme türü program temelli değerlendirmedir. Bu değerlendirme, doğrudan erken çocukluk eğitimi sınıfında uygulanan programın içeriği ve öğretim stratejilerini kapsamaktadır (Gullo, 2005). Programda kazandırılması 
düşünülen özel amaçlar yer almakta ve bu amaçlara ulaşılıp ulaşılamama durumuna göre gelişim ve program değerlendirilmektedir. Belirlenen amaçların ölçümü ise performans ölçümüne benzer şekilde gerçekleştirilmektedir (Mindes, 2003; Bagnato, McLean, Macy \& Neisworth, 2011; Neisworth \& Bagnato, 2004). Başka bir ifade ile de programın değerlendirilebilmesi için çocuklarla yapılan uygulamalar araç olarak kullanılmaktadır.

Program temelli değerlendirmenin; belirli program ve öğrenme deneyimlerinin çocuğa uygunluğunu belirlemek, çocuğun sınıf içerisindeki performansına uygun belirli program ve öğretim hedefleri geliştirmek ve o çocuğun gelişimini program üzerinden değerlendirme gibi üç temel amacı bulunmaktadır. (Gullo, 2005). Program temelli değerlendirmede çocukların performansı hakkında bilgi toplanacağı zaman bilinen tüm bilgi toplama uygulamaları kullanılabilmektedir (Deno, 2003). Değerlendirme yöntemi genellikle gelişime uygun mantıksal bir sıra ile öğretimi sağlamakta ve içermektedir (Gullo, 2005).

Sonuç olarak program temelli değerlendirme ile hem çocuk değerlendirilmekte, hem de çocuğun değerlendirilmesi aracılığı ile programın etkililiği belirlenmektedir. Programda aksayan yönler varsa yeniden düzenlenmekte ve daha etkili programlar oluşturulabilmektedir. Örneğin, erken çocukluk eğitiminde erken okuryazarlık gelişimi ile ilgili bir program hazırlanabilir. Hazırlanan program ve bu programın kazanım ve göstergelerine uygun bir değerlendirme yapılabilir. Bu kazanım ve göstergelere uygun olarak hazırlanan değerlendirme ile sonrasında hem çocuğun dil gelişimi değerlendirilebilir hem de çocuğun değerlendirilmesi ile programın aksayan, çalışmayan yönleri tespit edilebilir. Bu sayede ise program yeniden düzenlenerek kullanılmakta, aksaklıklar giderilmekte ve öncesinde ulaşmak istediği kazanım göstergelere de ulaşabilmektedir.

\subsubsection{Portfolyo}

Son alternatif değerlendirme yaklaşımı portfolyo ise eğitim programındaki amaçlar ile ilgili gelişmeleri görmeyi sağlayan çocukların süreç boyunca yaptıkları ürünlerin, çalışmaların sistematik olarak toplanıp organize edilmesi ile oluşan gelişim dosyalarıdır (Wortham \& Hardin, 2012). Başka bir ifadeyle portfolyo, çocuğun gelişimini ve öğrenmelerini en iyi şekilde yansitan örneklerin dosya üzerinde düzenlenmesi ve paylaşılmasıdır. Portfolyonun hazırlanma amacı; çocukların o andaki durumlarını ve ilerlemelerini belirlemek, öğretimi geliştirmek için yeni bilgiler elde etmek ve paydaşlara çocuk hakkında bilgi aktarmak olarak belirtilebilir (McAfee \& Leong, 2012). Çocukların sınıf içindeki ve sınıf dışındaki durumlarını, etkinliklerini ortaya çıkartan portfolyolar, çocukların bireysel olarak performanslarının saptanmasını sağlamaktadır (Erözkan, 2014). Portfolyolar, tüm değerlendirme sistemlerinin bir parçasıdır ve gelişim sürecini somut olarak da gösterebilmesi açısından eğitimdeki tüm paydaşlar için de oldukça yararlidir.

Esnek, amaçlı ve sistematik dosyalar olarak belirtilen portfolyoların temel amacı çocuğun öz disiplinini, sorumluluk bilincini geliştirmek ve kendini değerlendirme becerisi kazandırmaktır. Belirtilen amacın gerçekleştirilebilmesi için çocukların ne yapabildiklerine odaklanarak onların da aktif olarak katıldığı sürecin sonunda portfolyolar oluşturulmaktadır. Ayrıca, çocuğun gelişimini kanıtlarla ve daha gerçekçi biçimde izlemeyi, gelecekteki performanslarını yordayabilmeyi, gerçekte ne yapabildiğini gözlemleyebilmeyi ve ilgi alanlarını ortaya çıkarmayı hedeflemektedir. Bu 
süreçte portfolyo aşamalı olarak çocuğun tüm gelişim evrelerini de göstermektedir (Erözkan, 2014; McAfee \& Leong, 2012).

Portfolyo hazırlanırken amacının belirlenmesi, portfolyoya dahil edilecek belgelerin seçiminde çocuğun rolü, içeriğe dahil edilen belgelerde üzerinde bulunması gereken bilgiler dikkate alınmalıdır. Örneğin gelişimsel bir portfolyo hazırlamak amaç ise çocuğun gelişimini yansıtıcı belgeler seçilerek, sistematik bir şekilde dosyaya yerleştirilecektir (İvrendi, 2011). Portfolyolar genellikle, çocuğun okul yllı başında, ortasında ve sonunda yaptıkları tarih atılmış çalışmaları içermektedir. Bu sayede hem çocuk hem öğretmen kendi gelişimini görecek, aile ve diğer paydaşlarda çocuğun gelişimini farklı çalışmalar ve notlarla somut olarak gözlemleyebileceklerdir (Wortham \& Hardin, 2012). Tablo 11.'de 5 yaşındaki çocuk için hazırlanan portfolyo örnek sayfası yer almaktadır.

\section{Tablo 11.}

Portfolyo Sayfast

Adi-soyadi: Baran Kara

Bilişsel ve Psikomotor Gelişim \#Belge 1

Sene Başı $(X)$

Sene ortasi $(\mathbf{X})$

Tarih: 13.01.2017

Çocuğun başlattı̆̆ı ( )

Sene sonu()

Doküman \# 3: Beş yaşındaki çocuklar göz, burun, ağız, baş, gövde, kol ve bacaklarla birlikte detaylı bir şekilde çizebilirler. Baranın aşağıdaki çalışmaları okula başladığı ilk hafta ve bu dönem sonunda "kendini oyun oynarken çiz" etkinliğinden alınmıştır. Bu resimlerdeki ayrıntılar dönem ortasına kadar geçen süreçte Baran'ın detayları resme yansıtma, renkleri kullanma ve genel olarak resim çizme becerilerindeki ilerlemeyi yansitmaktadır.
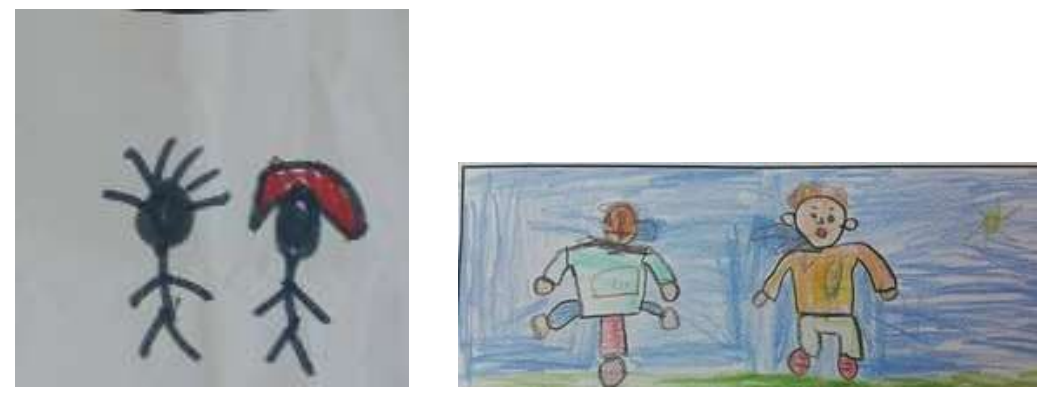

\section{TARTIŞMA, SONUÇ ve ÖNERILER}

$\mathrm{Bu}$ derleme çalı̧̧mada erken çocukluk döneminde ölçme ve değerlendirme ile ilgili temel yaklaşımlar ve kavramlar örnekleri ile sunulmuştur. Temel değerlendirme yaklaşımları olan standart testler kullanılarak yapılan formal değerlendirme, genellikle gözlem ve görüşme sonuçlarına dayalı yapılan informal değerlendirme ve bu yaklaşımlara alternatif olarak geliştirilen oyun temelli, dinamik ve program değerlendirme uygulama örnekleri ile birlikte açıklanmıştır. Bu çalışmada tanımlanan ve örnekler sunulan ölçme ve 
değerlendirme yaklaşımlarının alanda çalışan araştırmacı ve öğretmenlerin temel bir çerçeve oluşturmalarında katkı sağlayacağı düşülmektedir.

Ölçme ve değerlendirme ile ilgili bu yaklaşım ve kavramlar ayrıntılı olarak incelendiğinde ise her birinin ayrı bir amaca hizmet ettiği ama hepsinin bütününde çocuğun gelişimini tüm yönleriyle desteklemeyi amaçladığ 1 görülmektedir. Alanda oldukça çeşitli değerlendirme yöntemleri geliştirilmiştir ve bunlardan biri diğerinden daha üstün değildir. Standart testler hala özelikle tanı koymada geçerliliğini korusa da formal değerlendirme yaklaşımları eğitim sürecini değerlendirmede ön plana çıkmaktadır. Alternatif değerlendirme yaklaşımları her çocukların bireysel farklılıkları daha iyi tespit edebilmekte ve onlara uygun eğitim programı oluşturulmasında rehber olabilmektedir. Gerek alandaki araştırmacıların gerekse uygulayıcı olan öğretmenlerin kendi amaçlarına en uygun ölçme ve değerlendirme yaklaşımlarını seçmeleri ve sistemli bir şekilde kullanmaları önerilmektedir. Çocuğun gelişimin birçok faktörden etkilenen dinamik ve karmaşık (Berk, 2013) bir yapıda olduğu göz önüne alındığında farklı değerlendirme yaklaşımlarının kullanılması gerçekçi değerlendirme için gereklidir (Mindes, 2003).

Erken çocukluk eğitimin sınıflarında sistemli ölçme ve değerlendirme yapılaması ile ilgili çeşitli sorunlar vardır. Bu sorunların temel nedenleri olarak okul öncesinde ölçme ve değerlendirme ile ilgili yeterli kaynağın bulunmaması, üniversite eğitimi içerisinde alınan ölçme ve değerlendirme derslerinde okul öncesine yönelik çalışmaların sınırlı olarak yapılması veya hiç yapılmaması dile getirilmiştir (Varol, 2012). Bu nedenle alanda ölçme değerlendirmeye yönelik bu derleme gibi temel düzeyde daha çok sayıda yayınların yapılması ve alana özgü ölçme ve değerlendirme ders kitaplarının basılması önerilmektedir. Aynı zamanda, bu çalışmada söz edilen tüm değerlendirme yaklaşımları için ulusal düzeyde kültüre uygun çocukların gelişim ve öğrenmelerini ölçmek için çeşitli araçların geliştirilmesi ve öğretmenlerden tarafından sistemli olarak bu araçların kullanılması acil bir ihtiyaçtır. Ayrıca, alandaki öğretmenlerin sistemli ölçme ve değerlendirme yapmaları ve bu sonuçları ailelerle ve yetkilerle paylaşmaları konusunda bilinçlendirilmeleri yararlı olacaktır.

$\mathrm{Bu}$ derleme çalı̧̧ması ile en genel anlamda erken çocukluk eğitiminde ölçme değerlendirme ile ilgili yaklaşımların tanımlanması amaçlanmıştır. Bu nedenle temel düzeyde bu kavramları öğrenmeyi amaçlayan araştırmacılara ve öğretmenlere bu çalışma bir firsat sunacaktır. Öte yandan, bu çalışmada mümkün olduğunca çok farklı yaklaşım ve kavramı açıklama amacıyla her bir yaklaşımla ilgili sınırlı bilgiler verilmiştir. $\mathrm{Bu}$ konuda alandaki ihtiyaçlar göz önüne alındığında her bir yaklaşımla ilgili daha kapsamlı açılama ve örnekleri içeren makale ve kitapların yayınlanması önerilmektedir. 


\section{KAYNAKÇA}

Bagnato, S. J., McLean, M., Macy, M., \& Neisworth, J. T. (2011). Identifying instructional targets for early childhood via authentic assessment alignment of professional standards and practice-based evidence. Journal of Early Intervention, 33(4), 243-253. doi:10.1177/ 1053815111427565

Berk, L. E. (2013). Bebekler ve çocuklar doğum öncesinden orta çocukluğa (7.Baskı). (N. Işıkoğlu Erdoğan, Cev.). Ankara: Nobel Akademik Yayıncılık Eğitim Danışmanlık. (Orijinal çalışma basım tarihi 2011.)

Bergen, D. (2015). Play as a Method of assesing young children's development and learning: Past, Present, Future. Contemporary Perspectives on Research in Assessment and Evaluation in Early Childhood Education (Olivia Saracho Ed.) s. 221. Charlotte, NC: Information Age Publishing

Bodrova, E. \& Leong, D. J. (2010). Zihnin araçları: erken çocukluk eğitiminde vygotsky yaklaşımı (Tools of the mind: the Vygotskian approach to early childhood education). G. Haktanır (Çev. Ed. ) Ankara: Anı Yayıncılık.

Bredekamp, S. (2015). Erken çocukluk eğitiminde etkili uygulamalar (H.Z. İnan \&T. İnan Çev. Ed.). Ankara: Nobel.

Büyüköztürk, Ş., Kılıç Çakmak, E., Akgün, Ö. E., Karadeniz, Ş. ve Demirel, F. (2015). Bilimsel araştırma yöntemleri. Ankara: Pegem Akademi Yayınevi.

Ceyhan, A. A. (2011). Okul öncesi eğitimde gözlem tanımı, kapsamı ve önemi. A. A. Ceyhan \& M. Ören, (Ed.). Çocukları tanıma teknikleri içinde (s. 27-53). Eskişehir: Anadolu Üniversitesi Yayını No: 2273.

Colorado Department of Education. (2012). Child and family outcomes. Retrieved May 23, 2017 from http://www.cde.state.co.us/resultsmatter/childfamilyoutcomes.htm

Deno, S. L. (2003). Developments in curriculum-based measurement. The Journal of Special Education, 37(3), 184- 192.

Dinç, B. (2011). Aile ile işbirliğinde kullanılan teknikler: Anket ve görüşme. A. A. Ceyhan ve M. Ören (Ed.). Çocukları tanıma teknikleri içinde (ss. 127-158). Eskişehir: Anadolu Üniversitesi Yayını No: 2273.

Dykeman, B. F. (2008). Play-based neuropsychological assessment of toddlers. Journal of Instructional Psychology, 35 (4), 405-409.

Elibol, F. (2014). Alternatif değerlendirme. P. Bayhan, (Ed.), Her yönüyle okul öncesi eğitim: Okul öncesinde alternatif değerlendirme içinde (s.365- 375). Ankara: Hedef CS.

Ellingsen, K. M. (2016). Standardized assessment of cognitive development: instruments and issues. A. Garro (Ed.), Early childhood assessment in school and clinical child psychology in (p. 25- 51). New York: Springer.

Erözkan, A. (2014). Psikolojik danışma ve rehberlikte test dışı teknikler. Ankara: Mentis Yayınevi.

Geva, E. \& Wiener, J. (2014). Psychological assessment of culturally and linguistically diverse children and adolescents: a practitioner's guide. New York: Springer.

Glesne, C. (2014). Nitel araştırmaya giriş. (A.Ersoy ve P.Yalçınoğlu Çev.Ed). Ankara: Anı Yayıncilık.

Grigorenko, E. L., \& Sternberg, R. J. (1998). Dynamic Testing. Psychological Bulletin. $124,75-111$.

Gullo, D. F. (2005). Understanding assessment and evaluation in early childhood education. NY: Teachers College. 
Gullo, D. F., \& Hughes, K. (2011). Reclaiming kindergarten: Part I.Questions about theory and practice. Early Childhood Education Journal, 38, 323-328

İvrendi, A. (2011). Portfolyo değerlendirmesi. A. A. Ceyhan \& M. Ören, (Eds.), Çocukları tanıma teknikleri içinde (ss. 103-126). Eskişehir: Anadolu Üniversitesi Yayını No: 2273

Kelly-Vance, L., \& Ryalls, B. O. (2014). Best practices in play assessment and intervention. In P. Harrison \& A. Thomas, (Eds.), Best practices in school psychology: Data-based and collaborative decision making. National Association of School Psychologists. Bethesda, MD.

Kumtepe, A. T. (2011). Gözleme dayalı teknikler. A. A. Ceyhan \& M. Ören, (Eds.), Çocukları tanıma teknikleri içinde (ss. 53-77). Eskişehir: Anadolu Üniversitesi. Anadolu Üniversitesi Yayını No: 2273

Lidz, C. S. (1995). Dynamic testing and the legacy of L. S. Vygotsky. School Psychology International, 16, 143-153.

Lidz, C. S. (1991). Practitioner's guide to dynamic assessment. New York: Cuilford.

Linder, T. (2008). Transdisciplinary play-based TPBA2. Baltimore: Paul H. Brookes Publishing Co, Inc.

Losardo A., Notari-Syverson A. (2011). Alternative Approaches to Assessing Young Children (Second Edition) Baltimore, Maryland: Paul H. Brookes Publishing.

Maxwell, K. L.\& Clifford, R. M. (2004). Research in review: School readiness assessment. Young Children, 59, 42-46.

Mcafee, O. \& Leong, D. J. (2012). Erken çocukluk döneminde gelişim ve ögrenmenin değerlendirilmesi ve desteklenmesi (B. Ekinci Çev. Ed). Ankara: Nobel

McAfee, O., Leong, D. J. \& Bodrova, E. (2004). Basics of Assessment: A Primer for Early Childhood Educators. Washington D. C.: NAEYC.

Mindes, G. (2003). Assessing young children. NJ: Merrill Prentice Hall.

Neisworth, J. T., \& Bagnato, S. J. (2004). The mismeasure of young children: The authentic assessment alternative. Infants and Young Children, 17, 198-212.

Ömeroğlu, E., Büyüköztürk, Ş., Aydoğan, Y. vd. (2014). Okul öncesi çocuklar için sosyal beceri destek eğitimi ögretmen rehber kitabı (OSBEP). Ankara: Fikriala Görsel İletişim Hizmetleri

Ören, M. (2011). Okul öncesi eğitimde çocukları tanıma ve değerlendirme. A. A. Ceyhan \& M. Ören, (Ed.). Çocukları tanıma teknikleri içinde (s. 58-81). Eskişehir: Anadolu Üniversitesi Yayını No: 2273.

Özgüven, İ. E. (2002). Bireyi tanıma teknikleri. Ankara: Pdrem Yayınları.

Patton, M. Q. (2014). Nitel araştırma ve değerlendirme yöntemleri. (M. Bütün ve S. B. Demir Çev. Ed). Ankara: Pegem Akademi Yayıncılık.

Riley, K., Miller, G. E., \& Sorenson, C. (2016). Early childhood authentic and performance- based assessment. A. Garro (Ed.), Early childhood assessment in school and clinical child psychology in (p. 95-119). New York: Springer

Saracho, O. (2015). Contemporary Perspectives on Research in Assessment and Evaluation in Early Childhood Education. Charlotte, NC: Information Age Publishing.

Turgut, M. F. ve Baykul, Y. (2010). Eğitimde ölçme ve değerlendirme. Ankara: Pegem Akademi Yayıncilık.

Ünüvar, P. (2016). Görüşme. A. Önder (Yay. Haz.). Okul öncesi dönemde çocuklart değerlendirme ve tanıma teknikleri içinde (s.115- 125). Ankara: Pegem Akademi Yayıncılık. 
Varol, F. (2012). Anaokulu öğretmenleri konuşuyor: kaliteli eğitim. Uluslararası Katılımlı Çocuk İhtiyaçları Sempozyum Bildiri Kitabı, 29-35, MYÇ: Ankara.

Wright, R. J. (2010). Multifaceted assessment for early childhood education. CA: Sage.

Wodarski, J. S. (2015). Assesment methods. Wodarski, J. S., Holosko, M. J., \& Feit, M. D. (Eds.). Evidence-informed assessment and practice in child welfare in (p.99- 121). London, UK: Springer.

Wortham, S. \& Hardin, B. J.(2012). Assessment in early childhood education (6th Edition) NJ: Pearson.

Yıldırım, A. ve Şimşek, H. (2013). Sosyal bilimlerde nitel araştırma yöntemleri. Ankara: Seçkin Yayınevi. 
Erken çocukluk eğitiminde ölçme...

\section{EXTENDED ABSTRACT}

\section{Introduction}

Beginning of the prenatal period, humans encounter many assessments and evaluation procedures. After the birth, APGAR scale is used to determine the baby's health. Assessment and evaluation, generally play an important role in early childhood period to determine the process of development and learning in children. Considering enormous developmental changes in children from zero to six, in early childhood education uses various types of assessment and evaluation approaches which differ from the approaches other educational levels used for the assessment (Saracho, 2015).

Formal, informal, alternative and performance based assessments are widely used approaches in this early childhood education area. These approaches are often translated into Turkish from the global literature, and sometimes this leads to concepts contradictions. For this reason, this review study aims to describe the common approaches and concepts related to early childhood assessment and evaluation. The widespread approaches and concepts including formal, informal and alternative evaluation are discussed. In this context, the methods and tools are used to assess children's development are presented with examples of teachers and experts in the area.

In early childhood education, the concept of assessment and evaluation are discussed in the frame of developmental assessment. Therefore, the widespread definitions of assessment such as "observing the properties of objects and expressing the observational results with numbers or symbols" (Turgut \& Baykul, 2010) remain insufficient to explain the assessment and evaluation concepts fully in early childhood education. Assessment in early childhood education is defined as "a procedure used to determine the degree to which an individual child possesses a certain attribute" (Gullo, 2005) and "collect information about development" (McAfee \& Leong, 2012). The common issue emphasized in these definitions is that assessment is a concept used to define children's development. On the other hand, evaluation is defined as "the process of making judgments about the merit, value, or worth of educational programs, projects, materials, or techniques (Gullo, 2005). In other words, evaluation involves decision-making procedures based on assessment results.

In early childhood education, it is very important that assessment and evaluation procedures become part of children's natural life. Assessing children in their natural environment, such as home, school, and playgrounds ensure that valid and reliable information is obtained. At the same time, assessing all aspects of development instead of focusing on one or two developmental area will also ensure that the right decisions about their development are taken. Lastly, it is very important to use more than one assessment techniques and materials for capturing the whole development of the child (Gullo, 2005; Mindes, 2003; Saracho, 2015). Therefore, there are various approaches to assessment and evaluation. In general, these approaches can be defined as formal assessment, informal assessment and alternative assessment (Gullo, 2005).

Formal assessment is defined as using standardized tools to evaluate children's development and learning (Bredekamp, 2015). Formal assessment allows educators to compare an individual child's performance on the test to the performance of other children who have similar characteristics (Gullo, 2005). In this type of assessment, the reliable and valid measurement tools are used to determine the level of the child's development. Based on their 
functions, there are five types of formal assessment including "developmental screening tests, diagnostic tests, readiness tests, achievement tests and ability tests (Gullo, 2005; McAfee \& Leong, 2012).

The informal assessment contains nonstandard measurement tools such as observations, interviews, rating scales, check lists, rubrics and work samples of children's activities. Informal assessment should be used to assess the performance of the children and to inform instruction. An important advantage of the informal assessment is to assess the process of how children learn and use the knowledge and skills in the context of their classroom. On the other hand, an important disadvantage of the informal assessment is related to lack of the reliability and validity (Gullo, 2005). The most common informal assessment tool used in early childhood education is observation. Child observation can be used for various educational purposes and based on its purpose there are a variety of observational methods such as anecdotal records, running records, time and interval sampling. Another informal assessment tool commonly used in early childhood settings is interviewing with children and parents. Individual and group interviews give detail information about children's development and family context.

Alternative or authentic assessment is a form of assessment in which children are asked to perform real world tasks that demonstrate meaningful application of essential knowledge and skills. The main objective of the alternative assessment is to include learning environment as a part of the assessment process. This gives opportunities to assess children in their natural environments. The alternative assessment also requires an active participation of the teachers and children in the assessment process (Gullo, 2005; Mindes, 2003). Play based, dynamic, curriculum based and portfolio assessments are among the well-known alternative assessment types. Gullo (2005) defined the play based assessment as a process of systematically observing children while they are playing to obtain information about their developmental and academic skills. Home, school, playground and other natural settings in which children play, are used as an environment for the play based assessment (Dykeman, 2008). The term dynamic assessment is used as an assessment tool focusing on children's learning and their potential learning (Grigorenko \& Sternberg, 1998). Dynamic assessment focuses on the learning process rather than learning product as in traditional assessment (Lidz, 1991). Dynamic assessment derives its theoretical basis from Vygotsky's views on learning, development, and evaluation. Curriculum-based assessment is defined as assessment in which children's behavior in developmental, social, or academic areas are used as the basis for assessing the child, at the same time curriculum is used the basis for assessing the children's performances (Mindes, 2003). In this type of alternative assessment, the specific learning goals are designed, and children are assessed based to what extent they accomplished these learning goals. The last alternative assessment type is portfolio assessment. Portfolio assessment can be defined as the process of systematically documenting the children's work and performance to make educational decisions (Gullo, 2005). Portfolio assessment is commonly used in early childhood settings to document children's learning progress in the classroom context.

When these approaches and concepts related to measurement and evaluation are examined in detail, it seems that each approach serves separate purposes, but at the end, all aim to support the development and learning of the whole child. This review study suggests that appropriate assessment and evaluation approaches should be used in early childhood settings. 